\title{
THE TAXATION OF CORPORATE SURPLUS AND UNDISTRIBUTED INCOME ON HAND
}

\author{
J. V. DECORE*
}

\section{INTRODUCTION}

Whereas the profits reaped from an enterprise may be the same (all other factors being equal) regardless of whether the enterprise is operated as (a) a sole proprietorship or partnership, or (b) a corporation; the federal Income Tax Act ${ }^{1}$ will impose a different scheme of taxation in each instance. In the cases of a sole proprietorship and a partnership, the individual businessman is subject to graduated rates of tax in the year in which the profit is made, whether or not the profit is actually taken out of the business. However, for the same business activity carried on through a corporate entity, not only are the individual owners - shareholders-subject to tax when profits from the enterprise are distributed or deemed to be distributed, but the business entity itself is taxable on those profits. ${ }^{2}$ Thus, in effect, the present form of the corporate income tax presents a case of double taxation.

It has been argued that taxation of corporate profits followed by taxation of dividends received by shareholders is not double taxation of the same income; but, rather, is separate taxation of the income of two distinct entities-the corporation and the shareholder. Such an argument disregards the fact that, whether an enterprise is carried on by a corporation or a single proprietorship, the source of its income is one and the same. The legislators have themselves recognized this fact, as is evidenced by the twenty per cent rebate allowed by section 38 of the Act, by the low rate levied on the first $\$ 35,000.00$ of corporate taxable income, ${ }^{3}$ and by the right given to companies to capitalize certain earnings upon payment of a fifteen per cent tax. ${ }^{4}$ The cumulative effect of such provisions often places the private corporation in a position preferable to that of other forms of business organization. ${ }^{5}$

The concept of corporate taxation as it exists today is largely the result of play between three basic principles, namely: (a) that corporations are separate taxable entities, (b) that capital gains are to receive special treatment, and (c) that taxation should be levied at progressive rates dependent upon the financial position of the individual. ${ }^{\circ}$ The first and third of these principles are often in conflict with one another-a situation which has resulted in a complicated tax formula. The difficulty presented by this conflict could not be overcome by simply looking through the corporate veil in order to fix tax liability exclusively on individual shareholders. Shareholders have varying interests in companies, are in a constant state of turnover, and are for these reasons difficult to

\footnotetext{
- B.A., LL.B. (Alta.), LL.M. (Tor.), of the Alberta Bar.

1 R.S.C. 1952 , c. 148.

2 Of course, the individual shareholder is taxed only when such profits are distributed to the shareholders in fact or deemed to be distributed by the operation of the Income Tax Act.

3 Income Tax Act, s. 39

4 Id., s. 105 .

I Ivor, The Present Status of the Corporation Income Tax (1956), 4 C.T.J. 112, 118.

(i) Chomle, Surtax Avoidance and Extra Taxation of Corporate Earnings (1957), 5 C.T.J. 237.
} 
identify in relation to their interest. Neither could the difficulty be resolved by taxing shareholders on the deemed dividend basis; because, even if one could identify income with particular shareholders at all times, the actual flow of income from the corporation would seldom match the deemed dividend income and could result in levying a tax on amounts not received. Furthermore, the enigma was not to be overcome by taxing the corporation at progressive rates; for that, too, would yield inequity due to the fact that ownership of corporations varies widely, some companies being owned entirely by, perhaps, three men, and others by three thousand.

The upshot of all this is that, while the two concepts (of taxing a corporation at flat rates and taxing shareholders progressively) are opposed, the Finance Department seems to feel that neither should be entirely abandoned, since neither can function well alone. Hence, two taxes are imposed, one on the corporation at two flat rates ${ }^{i}$ and the other on individual shareholders at progressive rates. The result is a "lack of clear overall aims and objectives."

The purpose of this paper is to inquire into the mechanics of this "second" or individual aspect of taxation on corporate surpluses, and to study the principles underlying the notion of "undistributed income on hand" and its related concepts.

Three fundamental characteristics are stamped on the imposition of this "second" tax on corporate earnings." First of all, any form of distribution to shareholders by a dividend that is made while the company is a going concern is taxed in the hands of the shareholders regardless of the source. Secondly, because those monies are also taxed once at corporate rates, the second progressive tax should be mitigated. The Act, therefore, contains certain tax credit and saving provisions. Thirdly, corporate surplus, as a general rule, should not be subject to a further tax. Dividends are, therefore, allowed to pass between companies taxfree, subject to certain specific conditions.

As the mechanics of this scheme of taxation grew, over a period of time, it was found that these three basic concepts needed to be refined and that assurance had to be provided against tax avoidance schemes. Thus, provisions were drafted utilizing complicated formulae for "capitalization," and for "control periods." Further sections were enacted to deal with amalgamation, redemption or acquisition of preferred shares, non-resident corporations, tax-exempt persons, investment dealers, and so on. The ultimate result has been a snowballing of formulae and legislation that today cover some twelve per cent of the Income Tax Act.

The seemingly impossible task of grouping into classes the mass of patch-work legislation which surrounds this whole aspect of taxation has been done by G. T. Tamaki. ${ }^{10}$ According to his classification, the essential features of this system with regard to resident Canadian corporations and shareholders are as follows:

(a) corporate profits are taxed at two rates at the corporate level

\footnotetext{
7 Income Tax Act. s. 39.

8 Kelsey, Corporate Surplus, 1960 Conference Report (Canadlan Tax Foundation) 292, 294. - Gllmour, Canada Should Re-appraise Its Taxation of Corporate Surplus (1960), 8 C.T.J. 6.

11 Tax-Free Corporate Distribution in Canada, Feb., 1952, C.C.A. Vol. 80, No. 2.
} 
and at graduated personal rates on the deemed distribution of the balance as dividend;

(b) the shareholder is entitled to a twenty per cent dividend tax credit;

(c) inter-company dividends are normally tax-free;

(d) a dividend is deemed when the accumulated earnings are distributed indirectly;

(e) capitalization is permitted free of tax only to the extent that the earnings constitute "tax-paid undistributed income," pursuant to section 105;

(f) penal taxes are levied in situations that the regarded by the Finance Department as being improper avoidance methods of ordinary dividend taxes, as in section 8; and

(g) capital gain from the sale of shares are tax-free to the vendor even if the sale price includes undistributed corporate profit.

\section{EXPLANATORY REVIEW OF SECTIONS OF THE INCOME TAX ACT RELEVANT TO THE TAXATION OF ACCUMULATED SURPLUSES}

1. General

The policy of taxing corporate accumulations is reinforced with artificial formulae, "deem" provisions, tax concessions, and a variety of detailed legislation attempting to cover foreseeable (and unforseeable) avoidance schemes. Although a great number of sections of the Act are pertinent, discussion herein will be confined to the more important sections so as to avoid an unwieldy examination. Several of the minor sections, though related to his aspect of taxation, will be omitted. ${ }^{11}$

Under section 6 (i) (a), amounts received as dividends are to be included in computing the taxpayer's income and are payable by the individual shareholder, rather than the corporation. Where the shareholder does happen to be another corporation, the general rule is that inter-corporate dividends are received tax-free, pursuant to section 28 (1); but there is a major exception to this general rule, and certain dividends paid out of the undistributed income on hand of a corporation to its controlling corporation are subject to tax at full corporate rates. This legislation often becomes nothing more than a penalty provision, and the Act does go further in providing some alleviation in this regard.

The situation is somewhat different when dealing with accumulated earnings and deemed dividends rather than dividends actually paid. Although dividends paid are taxable irrespective of the fund from which the dividend is paid, dividends which are deemed to be received are limited to the lesser of the amount of the distribution or the shareholder's portion of "undistributed income on hand." Thus, if a corporation has not chosen to distribute profits until it is deemed wound up, the shareholders must pay personal rates on the amount received except to the extent that it exceeds the corporation's undistributed income on hand.

11 Moffet, Surplus Computations-Significance of Earnings in the Control Period, 1961 Conference Report (Canadian Tax Foundation) 119, sets out a comprehensive list of sections relating to this topic. 
Superimposed upon the above rules are provisions designed to give relief to double taxation, such as the twenty per cent dividend tax credit of section 38, or the distribution of accumulated earnings pursuant to the capitalization method provided for in section 105 . The provision in section 105 may be adopted by voluntary election, and is divided into amounts accumulated (a) up to 1949 , and (b) after 1949 . It will be noted that, where the fifteen per cent tax is payable, it is the corporation, not the shareholder, which is liable for such payment. The payment of that tax is followed by a tax-free capitalization and eventual distribution to the shareholder, which is usually accomplished by the issuance of redeemable preference shares.

In addition to other tax alleviating provisions, certain measures are aimed at avoidance schemes that circumvent tax by implementing intercorporate dividends, non-resident corporations, persons exempt from tax, dealers in securities, or amalgamation devices.

Blanketing all of these provisions is section $138 \mathrm{~A}(1)$ which substitutes ministerial discretion for the rule of law in dealing with tax avoidance schemes in this field sometimes referred to as "dividend stripping."

\section{(b) Undistributed Income on Hand}

Corporate surpluses may be derived from a great many activities and sources. Undistributed income on hand is comprised of a part of this surplus; and it sometimes becomes important to calculate undistributed income on hand because of the imposition of a tax upon the happening of certain contingencies. This will become apparent as we examine the specific sections of the Act. At this point, however, it should be realized that corporate surpluses and undistributed income on hand are not synonymous.

A certain amount of corporate profits must be utilized by a company to replace depreciating equipment, buildings, expansion, and so on. Therefore, whereas only a fraction of the total profits will ever be distributed to the shareholders; a considerable amount of these retained earnings will become designated as "undistributed income on hand" under section 82 of the Act, even though they are in the form of machinery or equipment. This does not usually present a problem to the larger corporations; but the private or family corporation will give serious consideration to the calculation of undistributed income on hand when one or more of the following events occur: declaration of a dividend, lending of money to shareholders of a company, control being taken over by another corporation, winding-up or discontinuance or re-organization of the business of the corporation, redemption or conversion of common stock into preference shares or some other obligation, amalgamation, or the death of a major shareholder."

\section{(c) Section 82}

Briefly stated, section 82 specifies undistributed income on hand as being the aggregate of incomes of a corporation for the taxation years beginning in 1917 and ending with the year in question minus the amounts calculated pursuant to clauses (i) to (viii) of section $82(1)$ (a).

12 Smith, Surplus Computations-The Importance of Undistributed Income, 1961 Conference Report (Canadian Tax Foundation) 110. 
It would appear that "incomes" of the corporation in the years prior to the current year would be calculated in compliance with the legislative provisions in force in that particular year. An older corporation may be required to go back some forty-five years to determine its "incomes" for the purposes of section 82; and it is foreseeably possible that this may cause no small degree of hardship, especially where adequate records, such as those made possible by today's more modernized and efficient methods of bookkeeping, have not been kept. The problem could become more confusing by reason of the existence of some doubt as to whether "incomes" of the past taxation years is equivalent to "income as assessed" at that time; and an assessment made by the Finance Department will not always be the answer to determing undistributed income on hand, in any event. For example, inter-company dividends received from another corporation may be tax-free to the receiver corporation, but such amounts must still be included in "incomes" for the purposes of section 82 . In other words, the assessments of previous years which set out "taxable income" have to be converted to figures representing "incomes." That the term "undistributed income on hand" is by no means synonymous with balance sheet references to earned surplus or re-invested earnings, or like descriptions, will become even more apparent when we turn our attention to the deductions allowed in computing undistributed income.

\section{(d) Deductions}

Sub-paragraph (i) of section 82 provides for the deduction of a loss in a taxation year; and it is open to question whether the "loss is determined by applying the provisions of the Act in force at the time attributable to the earning of the income, or whether the determination is to be made by the definition of loss under the present Act. Subparagraph (ii) permits the deduction of expenses and disbursements subject to those set out in sub-clauses (A), (B), and (C). Under subparagraphs (iii) and (iv), provision is made for the deduction of capital losses to the extent that they exceed capital gain, but it will be noted that a dividing line is drawn at the end of the 1949 year to tie in with section 105. It should also be realized that merely writing up or writing down the value of the corporation's capital assets as they appreciate or depreciate in value will not affect its undistributed income on hand; rather, the asset must be actually sold or rendered less (more) valuable by circumstances which cannot change its value to the company. ${ }^{13} \mathrm{Sub}-$ paragraphs (iv) (a) and following make specific allowances for the deduction of taxes which are self-explanatory on careful reading.

At this point, the bare definition of "undistributed income on hand" is complete. The remaining sub-sections of section 82 merely provide for computation methods and deal with cases of a special nature.

Section 82 (1) (b) sets out the procedure to be used in determining tax-paid undistributed income. It is here that this term is defined for purposes directly applicable to section 105. The individual shareholder's portion of the undistributed income on hand and tax-paid undistributed income is set out in section 82 (1) (c).

18 M.N.R. v. Consolidated Glass Ltd. (1957), 11 D.T.C. 1041. 


\section{(e) Section 81}

Dividends that are deemed to be received under the provisions of section 81 are limited to the lesser amount of the distribution, or the individual shareholder's portion of the corporation's undistributed income on hand as defined by section 82 (1) (c). Moreover, undistributed income on hand is reduced by the amount of tax-paid undistributed income as defined by section 82 (1) (b). In the day-to-day operations of a corporation, its undistributed income on hand does not present any problems and frequently will not even be computed. However, when any of the transactions enumerated in section 81 are carried out, the undistributed income on hand becomes a very real factor, in that its presence gives rise to a tax liability. In effect, not only does section 81 set out the transactions which will cause dividends to be deemed to be received; but it also acts so as to prevent distributions of a corporation's undistributed income on hand by means which would avoid the payment of the so-called "second" tax at personal rates.

Sub-section (1) of section 81 states that a distribution or appropriation of funds or property to the shareholders of a company with undistributed income on hand on the winding-up, discontinuance, or re-organization of its business shall be deemed to be a dividend received by the shareholders. The underlying purpose of this provision can be traced back to 1924 when the case of I.R.C. v. Burrell ${ }^{14}$ set down the common law rule that a distribution of accumulated income upon the liquidation of a company was not taxable, as it constituted a distribution of capital. Some authorities were of the opinion that the winding-up, discontinuance, or re-organization of a corporation's business might be different from the winding-up, discontinuance, or re-organization of the corporation itself, so long as the business was kept intact. However, the better opinion seems to be that this distinction cannot be relied upon ${ }^{15}$ to skirt the provisions of this legislation.

Section 81 (2) deals with the redemption, acquisition, or reduction of a corporation's common stock or a conversion of the common shares into shares other than common or some other obligation of the corporation; and declares that in each case a dividend will be deemed to have been received. ${ }^{16}$ The provision is designed to prevent distribution of funds or property through manipulation of the common stock without payment of tax. Sections $6(1)(\mathrm{g})$ and $105 \mathrm{~A}$ are closely related to the application of this section.

Section 81 (3) outlines the last of the three situations under which a dividend will be deemed to have been declared by virtue of this section, namely, where the whole or any part of a corporation's undistributed income on hand has been capitalized. Upon such an event occuring, each of the company's shareholders who held shares immediately before the capitalization shall be deemed to have received a dividend equal to the

14 [1924] 2 K.B. 52, 93 L.J.K.B. 709 (C.A.).

15 M.N.R. v. Merritt, [1942] S.C.R. 269.

16 A "common share" is defined for the purposes of the Income Tax Act in $s .139$ (1) (g); and it will be noted that the Income Tax Act definition of a common share does not necessarily correspond with the definition of common shares that are found in various provincial statutes. Therefore, one should be careful to note that, whereas a share having certain preferences (either as to payment of dividends or voting rights) may be a preferred share under provincial companies legislation, it could still be a "common" share within the meaning of that term in the Income Tax Act. 
shareholder's portion of the capitalized undistributed income on hand. Several questions have been raised with regard to the use of the term "capitalized" in this section, particularly dealing with the fact that the meaning of the term is uncertain. ${ }^{17}$ Although the matter may still be open to some question, Stewart Thom expressed what is perhaps the best view on the subject to date:

It now appears to be settled law in Canada that the appropriation of earned surpus to paid-up capital in the books of the company in some formal way effectively capitalizes the surplus. ${ }^{1 \mathrm{x}}$

The effect of section 81 (4) is to enable the taxpayer's portion of the corporation's tax-paid undistributed income to be subtracted from his income when a dividend is deemed to have been received by the provisions of that section. Tax-paid undistributed income is defined in section 82 (1) (b) of the Act, and the method of calculating the individual shareholder's portion of tax-paid undistributed income is set out in section 82 (1) (c). This section complies with the principle that corporate profits, generally, should not be taxed more than twice. Section 81 (5) also falls into line with this general rule; so that, where a dividend has been deemed to have been received under this section, the corporation's undistributed income on hand will be deemed to be reduced by the same amount.

Section 81(6) provides that, where a corporation pays a stock dividend, a capitalization shall be deemed to have been received for the purpose of section 81 (3) immediately before payment of the undistributed income on hand. Section $139(1)(k)$ states that a "dividend" does not include a stock dividend. Moreover, under section 8 (1) (c) (ii) a benefit conferred to a shareholder by a corporation shall be included in computing the shareholder's income unless, among other things, it was conferred by payment of a stock dividend. Thus, the combined effect of section 81(6) and $81(3)$ is to prevent a tax-paid distribution of a corporation's undistributed income on hand by using a stock dividend, which is not otherwise taxable.

Sub-section (7) provides for non-resident corporations, and declares that section 81 is not applicable in computing the income of the shareholder where the corporation is a non-resident; otherwise the section applies whether or not the corporation is resident or carries on business in Canada. A "non-resident corporation" is defined as a corporation "more than fifty per cent of the share capital of which (having full voting rights under all circumstances) belongs to non-residents."

Persons seeking to avoid tax have taken advantage of the phrase "having full voting rights under all circumstances" by issuing two classes of shares in their company. A nominal amount of low-priced Class A shares would have "full voting rights under all circumstances." Class B shares would also be issued, representing the real wealth of the corporation, having preference over the Class A shares, and granting to the owner all the powers of those shares with one minor voting limitation. The Class B shares might be issued far in excess of the nominal amount. of Class A shares, making the latter even more ineffectual. In such circumstances, on distribution of fifty-one per cent of the Class A shares

17 F. E. LaBrie, Introduction to Income Tax Law in Canada, 280-81 (1955 U. of Toronto Press).

18 Case Comment (1957), 35 Can. Bar Rev. 329. 
to non-residents, no one but the Finance Department would be concerned with the effects of section 81 .

Sub-section (8) was added to section 81 in 1954, providing that, where a corporation has increasd its paid-up capital otherwise than by (a) paying a stock dividend or (b) a transaction that increased its assets (or reduced its liabilities) by an amount not less than the amount by which its paid-up capital has been increased, the corporation's undistributed income on hand shall be deemed capitalized for the purpose of section 81(3). Authorities have raised questions in relation to subsection (8) such as: "What is meant by paid-up capital?" or "Does this section cover a debenture dividend?"19 Suffice it to say at this point that these provisions are not clear, and many questions surrounding them have not yet been answered.

\section{(f) Section 28}

The reasoning behind section 28 , again, falls into line with the philosophy that double taxation of corporate earnings is generally ample taxation. Hence, section 28(1) provides for dividends to pass from corporation to corporation tax-free. However, it was early discovered that this provision standing alone opened the door to numerous lucrative tax avoidance schemes. For example, suppose $X$ owned one million dollars worth of par value common shares in Corporation A. Suppose, further, that corporation A's activities were profitable, and that over a few years it accumulated one million dollars in income which would have been taxable if distributed directly to $\mathrm{X}$ in the form of a dividend. Corporation $B$ could be set up, and $X$ could sell his shares to that corporation for two million dollars, their fair market value at that time. Corporation $B$ could then borrow the required two million dollars from a bank and pay $X$ his due, which he would receive as a tax-free capital gain. Then a tax-free inter-corporate dividend of one million dollars could be paid to corporation $\mathrm{B}$ by Corporation $\mathrm{A}$, which could be repaid to the bank to cover part of the loan. Subsequently, the shares could be re-sold to $\mathrm{X}$ for one million dollars, again a fair market value at this stage; and the money could be given to the bank in full payment of the remaining loan. In effect, $X$ would then have his shares and, except for paying for the bank's services, he would have received Corporation A's corporate surplus tax-free. To avoid such a device, additional legislation was required; and subsections (2) to (12) of section 28 set out the concept of designated surplus designed to restrict the use of the inter-corporate relief measures as a means of obtaining, tax-free, undistributed income on hand.

Section 28 (2) provides that, where the payer corporation was resident in Canada and controlled by the receiver corporation, no deduction is permitted under section 28 (1) if the payer corporation had undistributed income on hand at the end of the last taxation year before control was acquired. That undistributed income is referred to as "designated surplus," and no amount is deductible under section 28 (1) if the dividend was paid out of designated surplus. If only a portion of the dividend was paid out of designated surplus, the exemption under section 28 (1) still applies to the remainder. In such circumstances, the dividend is taxed at

19 Ante, n. 17, at 281. 
full corporate rates, which may be as high as fifty per cent. In fact, in certain situations, when the dividend is again paid to the shareholders of the receiving corporation, it may again be subject to tax. This is, in effect, a triple taxation. One should note that the designated surplus concept has as its basis two features, namely, (a) undistriubted income on hand and (b) corporate control. Thus, the dividend paid in the circumstances is regarded as being paid from two sources, being: (a) from designated surplus and (b) from "control period" earnings of the payer corporation which may be paid tax-free pursuant to sub-section (1).

Sub-sections (3) to (12) largely concern themselves with a further curtailment of the tax-free inter-corporate dividend concept and are supplemented with sections such as $105 \mathrm{~B}$ and $105 \mathrm{C}$ in an attempt to plug all forseeable loopholes.

The over-all effect of section 28 is, on the one hand, to provide some relief against multiple taxation; but, on the other hand, to preserve the double taxation principle. Some anomalies have already begun to appear, as scrutiny of sub-sections (2) to (12) will indicate; and more will appear as we move on to analyze further sections in the Act.

\section{(g) Section 8}

Section 8 really supplements section 81 , causing property appropriaations and benefits conferred by a corporation on any of its shareholders to be treated as income of that shareholder according to the value of such benefits unless the appropriations are made as stipulated in paragraphs (i), (ii) and (iii) of section 8 (1) (c). Moreover, the case of Sabot v. M.N.R.20 makes it clear that, where the taxpayer is assessed under section 8 , he cannot take advantage of the twenty per cent dividend tax credit pursuant to section 38 . The result is a harsh penalty clause which, in the writer's opinion, is not warranted.

\section{(h) Relieving Provisions}

\section{Section 38}

Reference has been made to section 38, whereby an individual Canadian resident taxpayer may deduct, from the tax he would otherwise pay, twenty per cent of the aggregate of all dividends received (or deemed received) from a corporation resident in Canada that was not tax-exempt under Part 1 of the Act. From this aggregate the taxpayer must first deduct any amounts deductible under section 11(2), under the regulations, and deductible expenses incurred for the purpose of earning this dividend income. Sub-section (4) of section 38 makes an exception to this relieving provision with respect to the Old Age Security Act.

This does not mean, however, that where a shareholder has less tax to offset than the amount of the dividend credit a refund is granted for the excess.

Section 38 and section 105 contain the two main provisions of the Act relieving against double taxation. It should be noted that the taxpayer cannot take advantage of both of these relief measures, but must choose between them. The choosing involves arriving at the minimum tax position between the two alternatives.

20 (1955), 9 D.T.C. 321 


\section{Section 105}

Under section $105(1)$, a corporation may elect to pay a tax of fifteen per cent of its 1949 undistributed income on hand less its tax-paid undistributed income on hand at that time; or, alternatively, if its undistributed income on hand (less tax-paid undistributed income) at some subsequent year is less than it was in 1949 , the corporation may make a fifteen per cent election on the lesser figure under sub-section (1a). This latter provision was added to the Act in 1958, and is a realistic recognition on the part of the Finance Department that some corporations might suffer from adverse business conditions even after 1949.

A corporation (other than a subsidiary, controlled corporation with a greater undistributed income on hand in 1949 than tax-paid undistributed income) which has made the election under sub-section 1 or (1a) may elect to pay a fifteen per cent tax on an amount not exceeding the dividends paid by it since 1950 or deemed to have been received by its shareholders by virtue of section 81, minus amounts on which taxes have been paid under sub-section (2a) or (2b). (Those sums that were not taken into account in computing shareholders' income by virtue of section 81 (4) and section 141(1) are excepted.) The limitation to corporations other than subsidiary corporations is made to prevent a company from purchasing a subsidiary with a great deal of undistributed income on hand and causing the subsidiary to take advantage of the fifteen per cent election, thereby creating tax-paid undistributed income from post1949 surplus, which would ultimately be distributed to the parent company shareholders without further tax. These monies would then be applied toward the purchase price of the share of the subsidiary.

These provisions tie in with the notion of tax-paid undistributed income under section $81(4)$, by which tax-paid undistributed income is subtracted from the dividends deemed received, pursuant to section 81 , and from undistributed income on hand, as defined by section 82 . Thus, after a corporation has made the fifteen per cent election, the remaining surplus or "tax-paid undistributed income" can be appropriated to the shareholders tax-free, provided that it is done in accordance with section 81 and that this final distribution of profit will not be made until the year following the declaration of the dividend.

At such a stage, then, a corporation's undistributed income may take one of three forms, namely, (a) tax-paid surplus, (b) undistributed income convertible to tax-paid income on the taking of the section 105 election, or (c) current undistributed income not yet dealt with by the company. When it is desired to distribute the tax-paid portion of the surplus, care must be taken with regard to the manner in which the distribution is effected, as this can only be done on a winding-up or capitalization in accordance with the regulations. Even where the fifteen per cent has already been paid pursuant to section 105 , the tax-paid portion of surplus will again be subject to tax at personal rates if distributed directly as a dividend, or if not distributed in strict accordance with the capitalization methods permitted. The ultimate effect is that this leaves only a few capitalization methods by which tax-paid undistributed income may be paid out tax-free. The most common method is to create preference shares which are then redeemed. This may be 
done by the payment of a stock dividend by the corporation to its shareholders. The remainder of section 105 provides certain elaborations of the principle set out above, including rather stringent procedural rules that the taxpayer must follow to the letter in order to reap the allowed benefits.

\section{Section $105 A$}

Section 105 A provides that a corporation shall pay a tax on the amount of a premium paid for the redemption or acquisition of any of its shares other than common shares, which rate will be either twenty per cent or thirty per cent, depending upon the circumstances set out in that section. The need for sub-section $105 \mathrm{~A}$ arose out of abuse of the following loop-hole with respect to undistributed income on hand. Where a corporation with considerable surplus existed, a holding company could be incorporated with very little common stock, but with a great deal of redeemable notes or shares. The holding company could buy the shares of the business company in return for the redeemable notes and shares, and then declare a tax-free inter-company divided unto itself. Thereupon, these dividends, as "capitalized" assets of the holding company, could be passed on to the shareholders of the business company by redemption of the holding company's notes or preferred shares free of tax. The two companies would then be nothing more than empty shells; although the business company would still have a great deal of undistributed income on hand on its books, the Finance Department would realize no tax on it. Since section 81 (2) is confined only to the redemption of common shares, a provision of this type was needed with respect to preferred shares.

A point worth noting in this regard is that, since the special tax under this section is deductible itself in determing undistributed income, the tax rate actually boils itself down to sixteen and two-thirds per cent rather than twenty per cent, and approximately tweny-three per cent rather than thirty per cent.

\section{Section $105 \mathrm{~B}$}

Under section $105 \mathrm{~B}$, where a corporation other than an non-resident owned investment corporation has paid a dividend out of what would otherwise have been designated surplus at a time that the corporation was controlled by (a) a non-resident corporation, (b), a person exempt from tax under section 62 (such as a charity but excluding a personal corporation), or (c) a trader or dealer in securities, that corporation must pay a tax. Such tax would be levied on the amount of the dividend that would have been designated surplus, at a rate of fifteen per cent in the cases of corporations controlled by a non-resident corporation or by a person exempt from tax under section 62 and at a rate of twenty per cent in the case of a corporation controlled by a trader or dealer in securities. The remainder of the section provides specific rules for the general principles set out above.

The need for section $105 \mathrm{~B}$ resulted from avoidance schemes that were designed to circumvent the designated surplus provisions in section 28 . An example of such schemes involved the use of an investment dealer. When a company had a large accumulation of surplus, it would become 
designated if it passed to an ordinary corporation. The shareholders would sell their shares to an investment dealer at a fixed price. The investment dealer thereby obtained control of the corporation and would then cause it to pay its surplus to him by way of a dividend. The dealer then liquidated the corporation and thereby incurred a loss equal to the dividend which he had previously received. This loss cancelled out the "profit" made by the dealer; and, therefore, the concept of designated surplus was destroyed and the monies were subsequently distributed without anyone having to pay tax. Shareholders similarly disposed of their shares to non-resident corporations and persons exempt from tax under section 62 , each of which methods ultimately resulted in a tax-free distribution.

Perhaps the reader has already noted that the application of section $105 \mathrm{~B}$ is dependant upon "control" of the corporation in question, meaning ownership of more than fifty per cent of the corporation's issued share capital "having full voting rights under all circumstances." One avoidance practice which had been developed employed the securities dealer scheme to strip dividends as described above; in a more recent scheme two securities dealers rather than one were used, each having exactly fifty per cent ownership of the corporation's shares and neither possessing control of the company.

Once again arithmetical computation will indicate that the fifteen per cent rate really amounts to 13.043 per cent and the twenty per cent rate is in fact sixteen and two-thirds per cent, since the special tax under this section, too, is deductible in determining undistributed income.

\section{Section $105 \mathrm{C}$}

Section $105 \mathrm{C}$, enacted in 1959, is intended to operate hand-in-hand with section $85 \mathrm{I}$, dealing with corporate amalgamations. Prior to the enactment of section 85 I in 1958, a great many tax problems arose whenever two or more companies would merge. The main items of importance in section $85 \mathrm{I}$ were the following: (a) its elimination of the use of negative quantities of undistributed income on hand of one of two merging corporations acquired to lower the surplus of the other; (b) its protection against a re-designation of designated surplus; ${ }^{21}$ and (c) its creation of a major loop-hole, of which full advantage has been taken by $\mathbf{H}$. $\mathrm{H}$. Stikeman's clients. Section 85 I also provided that where Corporation A was a parent with a subsidiary Corporation B, which also controlled a subsidiary Corporation $\mathbf{C}$, an amalgamation of Corporations $\mathbf{A}$ and $\mathbf{B}$ (thus making Corporation $\mathrm{C}$ a subsidiary of the new Corporation $\mathrm{AB}$ ) would result in the carrying forward of any designated surplus that existed between Corporations $B$ and $C$; and such designated surplus would continue to be so earmarked. Similarly, positive quantities of undistributed income on hand of merging corporations were carried forward, as was undistributed income. Furthermore, for the purposes of section 105, the newly amalgamated corporation could make the 15 per cent tax election on 1949 undistributed income on hand of each of the predecessor corporations subject to the limitations set out.

In setting out the above pattern of tax provisions, the draftsmen overlooked an important detail. Section $28(2)$ defined designated sur-

21 Section 85 I (2) (1). 
plus as being a certain portion of a corporation's undistributed income on hand at the end of the corporation's last complete taxation year. However, an amalgamated corporation is a new body that does not have a previous taxation year. Thus, the Act covered the situation where a parent and a subsidiary amalgamated and continued to control a subsubsidiary; but, where a parent and a subsidiary amalgamated without there being a sub-sidiary, any designated surplus that had existed between them immediately disappeared. The undistributed surplus of the new company was no problem, of course, because dividends were merely stripped without concern for the concept of designated surplus.

The enactment of section $105 \mathrm{C}$ was therefore imperative, and came about in 1959 . Pursuant to this section, where a newly amalgamated corporation acquires the undistributed income on hand of its predecessors under section $85 \mathrm{I}(2)(\mathrm{k})$, it shall file a tax return and shall pay a tax of twenty per cent on the amount determined, minus the value of the assets of the new corporation (other than good-will) less its liabilities (aside from the tax liability of this section), as determined immediately after the amalgamation.

It will be noted that section $105 \mathrm{C}$ does not deal with "designated surplus" as such, but uses a rather different approach to obtain a twenty per cent tax. As a result of this fact, corporations have revived the old amalgamation scheme that was used prior to 1959 , by employing a slight adjustment. What is more, several difficult questions are raised by section 105 C-for example, what do "value" and "goodwill" mean?

It would appear to the writer that section $105 \mathrm{C}$ possesses at least three aspects. Firstly, it imposes a twenty per cent tax in certain amalgamation situations, which is inconsistant with the rates in other sections, notably section $28(2)$. It, therefore, acts as a concession. Secondly, some bona fide amalgamations fall within this provision; and the immediate tax liability, therefore, in effect, causes this section to act as a penalty. Thirdly, because it misses carefully planned schemes to avoid designated surplus and accumulated income, it acts as a tax avoidance lever.

The analysis of the major sections of the Act revolving around the notion of taxing undistributed income on hand is now complete for the purposes of his paper. It is hoped that the foregoing discussion has illustrated to the reader that this concept of taxation not only involves a considerable amount of legislation, but is also subject to many varied principles of taxation which are the result of patchwork legislation intended to close loop-holes. The plan contains supplementary amendments employing different rates, penalties, and concessions, thereby making this whole area a fruitful field for tax avoidance. ${ }^{22}$

As a last resort, section 138 A(1) was enacted in 1963 substituting ministerial discretion for the rule of law with regard to dividend stripping. This was a backward step in the history of federal income tax legislation, and it appears that the Finance Department has given up the battle of wits for the time being. Indications are that section $138 \mathrm{~A}(1)$ is a temporary measure taken by the Department pending overall reformation of the legislation surrounding this area of tax. The enactments in this

22 H. H. Stikeman, The Nature of Avoidance, Can. Tax Service Letter No. 71 (Feb. 26, 1962). 
field are nonetheless extremely confusing and inequitable. Moreover, even section $138 \mathrm{~A}(1)$ may not be entirely successful in closing all loop-holes and tax-avoidance schemes.

\section{TAX AVOIDANCE}

The art of tax avoidance involves minimizing or completely dissipating an intended tax in a manner not (seemingly) contemplated by the Finance Department. Mr. H. H. Stikeman has set out twelve tax minimization schemes, which are listed in the 1961 Conference Report of the Canadian Tax Foundation. The first four of these employ legislative methods approved by the Government, but the remainder were not contemplated by the Minister. The writer will briefly deal with avoidance schemes of the latter type. His purpose will not be to delineate avoidance schemes as such, because the application of section $138 \mathrm{~A}(1)$ will probably curtail these methods a great deal. However, some reference to these devices will be made to illustrate the weaknesses in the present legislation, which could only be overcome (in part) by substituting ministeral discretion for the rule of law.

Many of the avoidance schemes depend upon an interplay between two or more sections of the Act. To illustrate this fact, reference may be made to the gap which exists between section $28(2)$, whereby designated surplus is to be ascertained by reference to a corporation's previous taxation year, and section $85 \mathrm{I}(2)$ (a), the effect of which is that an amalgamated company, as a "new" corporation, could not have a previous taxation year. As a result of that gap, schemes employing the amalgamation of a company, such as Mr. Stikeman's "two-tiered tandem sidestep," 23 and Frank Jones' method of combining an amalgamation with the use of a non-resident corporation, ${ }^{24}$ have been successfully utilized.

Other avoidance levers work upon a fulcrum of combining intercorporate tax-free dividends and devices for eliminating "control," such as "stock splitting," thereby employing section 105 B. Usually, a nonresident person or an incorporated securities dealer is employed. ${ }^{25}$ The key to this series of devices is the subdivision of a corporation's shares into two classes, both being common shares, by taking advantage of the loophole that exists between section 139 (1) (a) and section 28 (3). A tax-exempt person such as a securities dealer is thereby allowed to eliminate "control," and thus sidestep not only the designated surplus concept but also the twenty per cent tax levied under section 105 . Mr. Tamaki employs a similar device, relying heavily upon this gap and particularly the phrase referring to common shares "having full voting rights under all circumstances." ${ }^{26}$

Closely related to the use of securities dealers and stock-splitting for tax avoidance is the exploitation of corporations. Messrs. Barbeau and Parkinson $^{27}$ have proposed an avoidance scheme which, in their submission, may well be effective despite the ominous presence of section

28 Can. Tax Service Letter No. 72 (May 10, 1962).

24 Unpublished thesis of Mr. Frank Jones, member of the Alberta Bar, p. 80.

25 Reference should here be made to Mr. P. N. Thorsteinson, who describes this type of scheme in meticulous detail in Undistributed Income, 1962 Conference Report (Canadian Tax Foundation) 150.

26 Ante, n. 6, at 438.

27 Dividend Stripping in Canada, 1965 C.C.H. pamphlet. 
$138 \mathrm{~A}(1)$. Since this section applies to a tax that "might otherwise have been payable under this Act in consequence of any distribution of income that has or will be avoided," a tax payable by a distribution of a non-resident corporation's funds to non-resident shareholders is not payable by virtue of the Canadian Income Tax Act.

Under the scheme proposed by Messrs. Barbeau and Parkinson, $\mathrm{X}$ and $\mathrm{Y}$ are the shareholders in Corporation $\mathrm{A}$ with undistributed income of, let us say $\$ 100,000.00$. Corporation $B$, an investment company, offers to purchase the shares of $X$ and $Y$ for their fair market value on behalf of an unknown client, Corporation $C$, which is resident in Nassau; and, on completion of the transaction, the shares are transferred to Corporation C. Corporation $\mathrm{C}$ now owns and controls the shares in Corporation $\mathrm{A}$, and causes Corporation $\mathrm{A}$ to change its residence from Canada to Nassau. Then, Corporation C liquidates Corporation A; the scheme is complete; and the application of section $138 \mathrm{~A}(1)$ is doubtful.

Various other techniques have been successfully employed, including the use of holding companies, parent-subsiduary relationships, or collapsible corporations; but no further elaboration on avoidance schemes need here be made.

In essence, these devices have been in constant use over the last decade; and, despite section $138 \mathrm{~A}(1)$, the offshore corporate technique may still be effective. Thus, we have a somewhat incoherent mass of legislation characterized by widely divergent tax rates and principles, unjustly excessive taxes in some cases, and a mass of loopholes in others, resulting in a potential tax ranging anywhere from nil to sixty per cent. The present legislation is most undesirable, and raises a serious problem that must be coped with.

\section{CRITICISM AND SUGGESTED ALTERNATIVES}

\section{Criticisms}

As a starting point for the criticisms directed to this whole taxation scheme, reference should be made to the inconsistency of rates, for it is from thence that the major difficulties stem. At one end of the scale we have sections 8 and $28(2)$, which could result in triple taxation or taxation without the aleviation of the twenty per cent dividend tax credit. At the other end of the scale are enactments such as section 38 and, indeed, the entire patchwork of legislation which permits courses of action whereby little or no tax is paid by the corporate shareholders. In between the two extremes, the inequities are aggravated by a number of sections which set out different tax rates based on different principles according to the distribution method followed by the taxpayers. For example, section 6, combined with the dividend tax credit, would make the tax dependent upon the shareholder's personal taxable incomes; and the section 105 series permits distributions at rates set at fifteen per cent, twenty per cent, or thirty per cent, which in fact result in rates of approximately twenty-three per cent, twenty per cent, sixteen and twothirds per cent, or 13.043 per cent. Hence, the taxpayer is left with (a) a lack of sureness in a sound basic principle of taxation in this field and (b) a poor attempt at integrating personal and corporate taxes. The 
results are complication, inequity, restriction on the free movement of capital, and relatively limited tax collection. ${ }^{28}$

Sections 105 and $105 \mathrm{~B}$, despite their inconsistent rates, provide some relief to this situation. But these hardships are not altogether done away with, and there is dissatisfaction with what is considered to be a further inequity between resident and non-resident companies in relation to the tax treatment of company dividends. When a resident Canadian Corporation purchases another surplus-laden corporation, that other corporation's surplus will become "designated"; and the purchasing corporation could be subject to a tax of twenty-one per cent to fifty per cent on a distribution of this undistributed income on hand. Section $105 \mathrm{~B}$ was passed to prevent dividend stripping through non-resident corporations, by imposing a tax liability of fifteen per cent. However, the ancillary effect of this provision was to place the non-resident corporation in a better position to purchase such a corporation than resident Canadian corporations. The alternative to the Canadian corporation would be to freeze this locked-in surplus; but this, in itself, is a matter which should be of concern regarding its effect on the economy. It would appear that the above-mentioned result is directly traceable to the loop-hole-patching method.

Most of the specific criticisms made by commentators have been directed at the concept of designated surplus, thereby indirectly attacking major principles underlying the "second" tax. Although the concept cannot simply be done away with without readjusting the whole scheme of taxation, it is open to valid attack on several major grounds, as indicated by $\mathrm{S}$. E. Edwards, namely:

1. It imposes a prohibitive penalty rather than a tax at a reasonable rate.

2. Its object is the wrong person-namely the purchasing corporation rather than the selling individual who is realizing the indirect tax-free distribution.

3. There are too many ways around it and accordingly it is ineffective. ${ }^{20}$

When he states that the concept is ineffective, S. E. Edwards refers to the fact that, because the rate is so high, the Finance department never collects any taxes directly as a result of the concept (except from the naive and unwary). The taxpayer will resort to one of the relieving sections in order to pay the tax at a lower rate. At the same time, the concept does have an adverse effect on bona fide corporate transactions. The fact that its sole raison d'etre is the closing of loop-hopes that cause inequities seems to justify the claim that the Finance Department is ignoring the full tax and economic consequences of its action. Year after year the joint committee of lawyers and accountants has submitted recommendations to the Department expressing its concern over this problem of designated surplus; but, to date, little has been done.

Another serious objection might be raised by the small shareholder, who may find that section $105 \mathrm{~B}$ actually acts to his disadvantage. When the majority shareholder finds that his financial position is such that the

28 Kelsey, Corporate Surplus, 1960 Conference Report (Canadian Tax Foundation) $292,297$. 20 Corporate Surplus, 1960 Conference Report (Canadian Tax Foundation) 300. 
twenty per cent tax is advantageous to him and thereby forces the corporation to make the distributions through a dealer, the smaller shareholder in the lower tax bracket is prevented from taking advantage of the section 38 tax credit. The effect of section 105B in this respect is actually discriminatory rather than relieving.

Other questions have been raised with regard to the provisions of section $85^{30}$ the use of charities in section $105 \mathrm{~B}(1)$ (c),,$^{31}$ and various other specific matters. All result from nothing more than inequitable and cumbersome legislation.

Mr. Edwards has set out six tests which determine the suitability of a tax: ${ }^{32}$ (1) whether the tax is related to the ability of the taxpayers to pay; (2) the effectiveness of the tax in the production of revenue to the Federal treasury; (3) its equity as between taxpayers; (4) certainty; (5) the effect of the tax on business and the economy; and (6) administrative feasibility. Needless to say, few will agrue with $\mathrm{Mr}$. Edwards' conclusion that the taxation of corporate surplus distributions fails almost every test, if not all.

\section{Suggested Solutions and Alternatives}

It is submitted that those sections of the Income Tax Act which deal with the second tax are inadequate in many respects, and that alternatives are needed. By directing the reader's attention to some of the solutions that have been suggested, the writer hopes that some constructive conclusions may be reached as alternatives to the present legislation.

Generally speaking, there are three classes of possible alteratives: firstly, the complete abolition of the second tax concept, either directly or by the introduction of legislation that would almost wholly do away with this principle for all practicable purposes; secondly, retention of the second tax concept as it is presently set out, but with improvement of the mechanics by which the concept is put into effect by altering certain specific provisions within the general framework of the concept; and, thirdly, retention of the second tax concept in principle, but utilization of a different set of mechanics that would, in effect, necessitate a complete revision of the present legislation.

The most straight-forward reasoning along the line of the first class is that of Mr. Jackett. He simply proposes that the "first" or corporate tax should be raised slightly, presumably to account for a loss of revenue to the Department, and that the second tax should then simply be forgotten about. This would make the Income Tax Act more simple, certain, and equitable. ${ }^{33}$ Support is given to the argument by the fact that many persons are exempt from the "second" tax (due to provisions such as the twenty per cent dividend tax credit), that some put off distribution indefinitely, and that others avoid the tax completely or reduce it considerably. Thus, the only effect of the second tax is to create artificial barriers, hampering the free movement of capital. It is further submitted, along this line of reasoning, that repeal of the "first" corporation tax and an increase in the second tax would only lead to more complications.

30 D. G. Scott, Holding Company Methods (1960), 76 C.C.A. 178.

31 George G. Richardson, Taxes, Accumulation of Undistributed Income, Consolidated and Mergers (1957), 70 C.C.A. 52 .

32 Corporate Surplus, 1960 Conference Report (Canadian Tax Foundation) $300 \mathrm{ff}$.

88 Id. at 285 . 
As far as theory is concerned, the writer has little quarrel with these proposals. However, it is felt that certain political facts of life make any suggestion that the second tax be done away with impractical; and we may as well resign ourselves to the fact that this tax is here to stay. The most serious obstacle to eliminating the second tax is the fact that any political party which, being in power in Ottawa, attempted to pass such a proposal would come under severe attack by opposition parties. The socialists have already campaigned on the basis that, whereas a labourer's pay cheque is subject to income tax, many persons who merely invest their money pay insufficient tax on the profits they receive. A complete abolition of this second tax would probably result in all of the opposition parties using this line of attack; and it is questionable whether the party in power could convincingly explain, as do some authorities, that the investor's money has already been taxed at personal rates and that any dividend received has previously been subject to the corporate "first" tax. This is not to suggest that those who support the abolition of the second tax are incorrect; but it is very doubtful that a governing party would want to put itself in the position of having to explain this to the voters. It is, thus, felt that the theoretical attributes of such a proposal would be out-weighed by other considerations.

Several authorities have stated that, assuming that the taxation of surplus accumulations is to be adhered to, the dividend tax credit should be increased from its present level of twenty per cent. Mr. Gilmour has suggested that it be raised to as high as forty-five per cent, and $\mathrm{Mr}$. Tamaki has considered a fifty per cent figure. These proposals are designed to encourage distributions. The writer finds it most difficult to accept these suggestions for two reasons. Firstly, the reason for the dividend tax credit was to more or less equalize the positions of $\mathrm{X}$ and $\mathrm{Y}$, each operating a similar businss, $\mathrm{X}$ as the major shareholder in a smaller corporation and $\mathrm{Y}$ as a sole proprietor. Presently, $\mathrm{X}$ can receive approximately $\$ 11,800.00$ in tax-free dividends after paying the first tax. In fact, so effective has been the twenty per cent tax credit, that it is often preferable to operate a business through a corporate body. However, a fifty per cent tax credit would permit $X$ to receive some $\$ 90,000.00$ in tax-free dividends. In other words, a fifty per cent tax credit would no longer tend to equalize the positions of $\mathrm{X}$ and $\mathrm{Y}$; but would swing the pendulum far the other way, which would thwart one of the very purposes of the enactment. Secondly, perhaps a more valid criticism of this legislation lies in the fact that it would almost entirely do away with the second tax, for it is felt that there are very few shareholders in Canada that are able to realize more than $\$ 90,000.00$ annually in dividend profits. In view of this fact, the party in power which would try to pass legislation allowing a fifty per cent tax credit would find itself in the same position as would a party which attempted completely to do away with the second tax. It is submitted that any suggestion of increasing the twenty per cent tax credit would fall on deaf ears.

Perhaps a more realistic approach to the problems created by the second tax is taken by those who assume that it is here to stay in some form or other. Most of these commentators accept the present procedural skeleton that is the basis for the tax, but would propose certain improve- 
ments within that framework. Various suggestions have been made with regard to improving the present mechanics of the system.

One suggestion included three aspects. The first involved the abolition of the distinction between ordinary distributions and deemed dividends, so that tax liability would arise only when ordinary distribution was made in fact. This would mean that the concept of undistributed income on hand would disappear. The second involved the replacement of the patchwork system with better legislation, such as, for example, the allowing of all inter-corporate dividends to be tax-free so long as they remain "surplus." The third aspect involved the supplementing of these features with more realistic rates by increasing the dividend tax credit to forty or forty-five per cent or, alternatively, taxing the liability on distributions at a maximum of five per cent. ${ }^{34}$ It would appear, however, that the employment of the first two branches of this plan would result in the creation of gaping loopholes (such as would allow escape from taxation through distribution of funds by winding-up or other capitalization procedures) that could only be closed by legislation similar to what we have at present. There is some argument that the tax rates on the second tax could be more realistic; but a tax credit of forty-five per cent or a maximum five per cent tax would all but abolish the second tax concept altogether.

At the 1955 Conference of the Canadian Tax Foundation, H. P. Herington made several proposals designed to improve this phase of taxation. He suggested, firstly, that the calculation of undistributed income on hand should begin at 1930 rather than 1917, which would eliminate calculations from corporate records that would be obsolete. In most cases, surpluses existing before 1930 would have been disbursed or lost in any event. ${ }^{3.5} \mathrm{He}$ also proposed that a taxpayer be entitled to know the amount of undistributed income on hand before making the election under section 105 . Since this amount cannot be calculated until the end of the year, and since the election is usually made on an estimate subject to a later assessment by the Minister, the taxpayer should be allowed to withdraw his election within a reasonable time after the assessment is made. Although Mr. Herington recommended that the provisions dealing with controlled corporations be removed, he seemed to accept the fact that the Finance Department would not likely assent to his proposal; and he alternatively suggested that all corporations acquiring control of other companies be in at least as favourable a position as traders or dealers in securities, by equalizing the tax rates between section 28 and section 105B. Finally, he suggested that interest and expenses should be allowed and properly considered when the tax is levied. For example, where a holding company disburses interest and expenses to earn income from one of its subsidiaries, such amounts should not be allocated in part to dividends received from the subsidiary. The only observation that the writer can make respecting $\mathrm{Mr}$. Herington's proposals is to note that they were made a decade ago, and to express some dismay that some of these suggestions have not been adopted to date.

34 A. W. Gllmour, The Case Against Designated Surplus (1960), 77 C.C.A. 250.

38 Since this proposal was made some ten years ago, Mr. Herington might today consider advancing the 1930 date even further. 
Many of the alternative improvements revolve around section 105 . The most obvious of them would be the equalization of the tax rates between section $28(2)$ and those of the section 105 series.

In addition, numerous authorities have observed that the "capitalization" requirement of distributing tax-paid undistributed income under section 105, rather than a direct distribution, is expensive, involved, and achieves no realistic purpose; it could well be overcome by a system of direct payment.

As has already been noted, the concept of designated surplus has been subject to a great deal of critical writing. It is to be expected, therefore, that many suggested solutions involve section 28 . Certainly the most common of those recommendations has been the standardization of the tax rates. One of the more intricate submissions regarding relief against the designated surplus provisions was put forth by Mr. Stikeman. ${ }^{36}$ It was based upon a time factor, whereby surplus would be designated only for a certain number of years (five years, for example) after which time it may be distributed tax-free. Current interest rates would prevent shareholders from borrowing funds from a bank to acquire a subsidiary and then repaying the loan with the sudsidiary's undistributed income on hand without incurring any tax liability. Mr. Campbell W. Leach took issue with this proposal:"7 by stating that a specified time limit would be a very arbitrary way of differentiating between tax evasion and a bona fide transaction.

Although complete abolition of designated surplus is recommended by several theorists on the subject; it would appear that, once we have adopted the second tax principle, the suggestion that a wide-open loophole be created is incongruous. While most lawyers would agree that the designated surplus concept is an example of muddleheaded thinking, merely abolishing it is not the complete answer; what is required in addition is a reasonable alternative that would prevent the creation of a gigantic loophole.

Alternative proposals have been put forward, some of which are quite elaborate. Mr. Edwards, for example, set out an eleven-point program at the 1960 conference of the Canadian Tax Foundation, which encompassed an alternative to the designated surplus concept, and which could also be used as a method of imposing tax on amalgamations. Perhaps the main drawback of Mr. Edward's proposal is that the legislation required to implement it would be nearly as cumbersome as our present provisions, particularly in its attempt to prevent all foreseeable methods of making distributions free of tax. However, Mr. Edwards does state that the tax should be imposed on "the person who should properly bear it," and it would appear that he is reaching for a solution that might well be extended so as to apply to the whole second tax system, rather than merely to the designated surplus problem. Mr. Tamaki, himself, acknowledges that the most effective method of collecting a tax is to make it payable at the source.

In effect, this brings our discussion to the last school of thought, namely, that, while a second tax should be maintained in principle, the 
mechanics of implementing it should be completely changed. The writer suggests that the key to this major alternative lies in extending $\mathrm{Mr}$. Edwards' proposal by re-allocating the source from which the tax is to be extracted-that is, from the surplus-holding corporation. It is submitted that aspects of the English system of taxation might well be adopted so as to utilize the principle that the source of taxation should be at the corporation level; so that, in effect, the shareholders would be bearing the tax at rates which would be dependent to a large degree upon the financial status of the individual shareholder.

The English corporation's income is taxed, firstly, at a flat rate, whether or not its earnings are distributed. Thereafter, the corporation is required to withhold a standard rate of income tax on behalf of its shareholders. Thus, the corporation, and not the shareholder, is directly responsible to the treasury for the tax. If the shareholder's personal rate of tax is less than the standard rates so withheld, he is entitled to claim a refund from the Commissioner.

Canada's dividend tax credit provisions could fit quite nicely into this mechanism. Dividends received by corporate shareholders in England are allowed to pass tax-free under certain circumstances. This is not to suggest that the implementation of the English system in its entirey would be a complete answer to the Canadian problems. Changes would be necessary where local conditions warranted them. Nor does the writer submit that this system is foolproof. It is understood that tax avoidance devices keep lawyers and accountants busy even in England, although perhaps not to so great a degree as in Canada. But this much is clear, namely, that the present patchwork legislation is completely unsatisfactory. It is submitted that, while a second tax is probably here to stay, we require a complete reappraisal of the mechanics of implementing it; and it is submitted that the English system, in modified form so as to conform with our own needs, would put the second tax notion to work effectively without causing loss of sight of our principles of progressive taxation.

\section{CONCLUSION}

Paul A. Samuelson ${ }^{38}$ once commented on what is known as the confidence theory with respect to government monetary policies. The proponents of this theory advocate that, in order for a nation's economy to prosper, there must be confidence in the government's handling of the country's fiscal matters. This is not to be confused with an emotional confidence; but is, rather, a confidence based on a profit incentive which is brought about by stable fiscal policy in the present and for the future such as will stimulate investment and growth. Although this confidence factor cannot be measured in concrete terms, it is nevertheless vital. Corporate business in Canada, and particularly that carried on by the private or family corporations, is of major importance to the country's fiscal disposition. Yet, the writer can think of nothing that undermines the confidence factor more effectively than the irrational, irregular principles and the patchwork legislation which has been the subject matter of this paper.

38 Professor of Economics at the Massechusetts Institute of Technology. 
Until recently, the gross tax receipts from the implementation of this second tax were less than fifty million dollars per annum. This rather negligible amount is more than offset by the restraints imposed upon corporate private enterprise in Canada. These provisions of the Act do more than their share in hindering the economy, as is apparent from some of the effects that they have on corporate business, such as hampering bona fide business transactions of purchase and sale, mergers, acquisitions, dividend payments, or encouraging or forcing corporate sellouts (often to foreign interests), liquidations, asset freezing, and avoidance schemes. As if this were not enough, the guiding principles contain the elements of confusion, inequity, uncertainty, shallow loophole-plugging, and a who-knows-what's-next attitude. It is felt that the suggestion that these provisions are a hindrance to the economy is not an unwarranted conclusion. This is not altogether a submission that the Department should be more concerned with using taxation as a tool to encourage or discourage certain aspects of business in our society rather than collecting revenue for its own fiscal programs. This is often a difficult task. But when a tax is levied with a complete disregard for the adverse effects that it has on private enterprise merely to squeeze a little more revenue into the coffers, it is suggested that all is not well. Nor does the writer propose that the only alternative is to do away with the second tax notion completely, for a properly planned system could result in a realization of government revenue without hampering corporate business and economic expansion.

For these reasons, it is submitted that the problems raised herein are of major importance, affecting not only a certain portion of federal legislation or government revenue, but the economy of this country as a whole. An entirely new approach must be taken with respect to the implementation of the tax on corporate surplus. 